\title{
Augustine's Interpretation of Matthew 5:17 and Its Historical Context
}

\author{
JOHN A. LORENC \\ $1^{\text {st }}$ Year, MA, Religious Studies \\ McMaster University \\ Hamilton, Ontario
}

\section{Introduction}

The interpretation of Matt 5:17 — the problem of the abiding validity of the law in the First Gospel— has been a major point of debate in contemporary Matthean studies. ${ }^{1}$ No doubt this interest in the status of the law in Matthew springs in part from the fact that, as Peter Hebblethwaite remarks, "the discussion of Matthew 5, 17 opens up the whole question of the relationship between Judaism and Christianity, whose closeness has so often taken the form of rivalry or enmity."2 Ulrich Luz has recently proposed that the study of the history of interpretation of a biblical text may assist modern biblical scholars in developing a fresh perspective on the text's "directional” meaning (i.e. the text's significance for the present, related to, but distinct from, its particular historical significance). ${ }^{3}$ To this end, I shall discuss St. Augustine's interpretation of Matt 5:17 in his commentary on the Sermon on the Mount and Contra Faustum Manichaeum in order to determine his understanding of the status of the law in

\footnotetext{
1 See, for example, the recent studies of David L. Balch, "The Greek Political Topos $\pi \varepsilon \rho i$ vó $\mu \omega v$ and Matthew 5:17, 19, and 16:19," in Social History of the Matthean Community, ed. David L. Balch (Minneapolis: Fortress Press, 1991), Anthony J. Saldarini, Matthew's Christian-Jewish Community (Chicago: University of Chicago Press, 1994), 124-64, Klyne Snodgrass, "Matthew and the Law," in Treasures New and Old: Recent Contributions to Matthean Studies, ed. David R. Bauer and Mark Allan Powell (Atlanta: Scholars Press, 1996).

${ }^{2}$ Peter Hebblethwaite, "St. Augustine's Interpretation of Matthew 5,17," in Studia Patristica, ed. Elizabeth A. Livingstone (Berlin: Akademie Verlag, 1985), 511.

${ }^{3}$ Ulrich Luz, Matthew in History: Interpretation, Influence, and Effects (Minneapolis: Fortress Press, 1994), 50, Ulrich Luz, Studies in Matthew (Grand Rapids: Eerdmans, 2005), 304.
} 
Matthew's gospel. ${ }^{4}$ Moreover, since Luz has also remarked that in the history of interpretation of the Bible, "there was never an interpretation of a text that did not bear the mark of the historical situation of its interpreter," I shall also show the historical reasons Augustine may have had for arriving at his understanding of Matt $5: 17 .^{5}$

\section{Augustine's Understanding of the Abiding Validity of the Law in the Gospel of Matthew}

\subsection{Matt 5:17 in Augustine’s De Sermone Domini in Monte Secundum Matthaeum}

In his commentary on the Sermon on the Mount, Augustine argues that Christ upholds the validity of the law by adding to it. Augustine explains that the law can be fulfilled in two ways: either by "adding what is wanting" or by "doing what is in it" (I.VIII.20). ${ }^{6}$ He does not take up the latter way in this work (he will discuss it in Contra Faustum Manichaeum). With respect to the former way, he argues that to fulfill the law by adding to it does not destroy it, but perfects it, for "if even those things which are added for completion are fulfilled, much more are those things fulfilled which are sent in advance as a commencement" (I.VIII.20). ${ }^{7}$ According to Augustine, Christ fulfills and perfects the law not by insisting upon a new law, but by demanding

\footnotetext{
${ }^{4}$ Augustine, "Our Lord's Sermon on the Mount, According to Matthew [De Sermone Domini in Monte Secundum Matthaeum.]," in A Select Library of the Nicene and Post-Nicene Fathers of the Christian Church, ed. Philip Schaff (Grand Rapids: Eerdmans, 1956); Augustine, "Reply to Faustus the Manichaean [Contra Faustum Manichaeum]," in A Select Library of the Nicene and Post-Nicene Fathers of the Christian Church, ed. Philip Schaff (Grand Rapids: Eerdmans, 1956).

${ }^{5}$ Luz, Matthew in History: Interpretation, Influence, and Effects, 26. In pursuing this topic I shall be building on Hebblethwaite's study of Augustine's interpretation of Matt 5:17, since Hebblethwaite only treats Augustine's discussion of Matt 5:17 in Contra Faustum Manichaeum and provides only a very brief account of some of the historical considerations underlying Augustine's interpretation.

${ }^{6}$ Augustine, "Our Lord's Sermon on the Mount, According to Matthew [De Sermone Domini in Monte Secundum Matthaeum.]," 10. My practice when citing Augustine's works has been to provide the reference in Book.Chapter.Section, etc. format in parentheses so that the reader may locate the quotation in other editions, followed by a full reference to the particular edition I have used.

${ }^{7}$ Ibid.
} 
a greater degree of righteousness in the performance of the existing law. The understanding and performance of the law before Christ's teaching corresponds only to the lesser righteousness of the scribes and the Pharisees described in Matt 5:20. The scribes and the Pharisees keep only the least of the commandments (Matt 5:19), i.e. the law prior to Christ's addition. Interpreting Matt 5:19-20, Augustine establishes a hierarchy of those in the kingdom of heaven: at the bottom are those who do not even perform the least of the commandments; in the middle are those who perform these (the scribes and the Pharisees), but no more; at the top are those who "do and teach as Christ now teaches" (I.IX.21). ${ }^{8}$ Augustine illustrates this hierarchy practically in his discussion of the meaning of Matt 5:21-22:

The righteousness of the Pharisees is, that they shall not kill; the righteousness of those who are destined to enter into the kingdom of God, that they be not angry without a cause. The least commandment, therefore, is not to kill; and whosoever shall break that, shall be called least in the kingdom of heaven; but whosoever shall fulfil that commandment not to kill, will not, as a necessary consequence, be great and meet for the kingdom of heaven, but yet he ascends a certain step. He will be perfected, however, if he be not angry without a cause; and if he shall do this, he will be much further removed from murder. For this reason he who teaches that we should not be angry, does not break the law not to kill, but rather fulfils it; so that we preserve our innocence both outwardly when we do not kill, and in the heart when we are not angry. (I.IX.21) ${ }^{9}$

From this it is clear that, for Augustine, Matt 5:17 indicates that the law is still fully valid; under Christ it has simply become more exigent. In the case of murder, what the law had forbidden the believer to do, Christ now forbids the believer even to contemplate. Christ's addition to the law does not change its intention, but amplifies its demands in the fulfilling of that intention. Here, too, we may note, for Augustine, Christ's interpretation of the law has shifted from a focus on

\footnotetext{
${ }^{8}$ Ibid., 10-11.

${ }^{9}$ Ibid., 11.
} 
the believer's outward actions to his inward intentions. This shift in focus from the exterior to the interior will also inform Augustine's understanding of how Christ fulfills the ritual law.

Although Augustine affirms that Matt 5:17 means that even the "smallest particulars" of the law are to be "carried into effect" (I.VIII.20), ${ }^{10}$ he does not believe that this applies to the ritual aspects of the law. Unfortunately, Augustine does not explicitly discuss the abiding validity of the ritual law here (though he does in Contra Faustum Manichaeum); however, his interpretation of the significance of the altar in Matt 5:23-24 suggests that he did not understand the ritual law still to apply literally after Christ's fulfillment of the law. According to Augustine, Christ does not admonish the reader in these verses to be reconciled to his brother in person before presenting his offering at a physical altar, but he admonishes the reader to be reconciled inwardly with his brother and thus "we may interpret the altar spiritually, as being faith itself in the inner temple of God, whose emblem is the visible altar" (I.X.27). ${ }^{11}$ For Augustine, the altar in Matt 5:23-24 resides within the temple of God in the inner man as described in 1Cor 3:17 (I.X.27). ${ }^{12}$ If the ritual law abides after Christ, then it does not abide in the same way that the injunction against murder abides. The latter persists in its literal force while the former takes on a new spiritual significance within a Pauline interpretive framework.

\subsection{Matt 5:17 in Augustine’s Contra Faustum Manichaeum}

In Contra Faustum Manichaeum, Augustine takes up the second way in which he explained that the law could be fulfilled - by "doing what is in it" — in response to his opponent Faustus' objection that Christ cannot fulfill the law since Deut 12:32 expressly forbids adding to

\footnotetext{
${ }^{10}$ Ibid., 10.

${ }^{11}$ Ibid., 12-13.

${ }^{12}$ Ibid., 13.
} 
the law (XVII.2). ${ }^{13}$ On account of this injunction, Faustus claims that the law that Christ speaks of in Matt 5:17 is not the law of the Hebrews. Faustus supports this claim with the observation that in the "antitheses" (Matt 5:21-48) Christ does not speak of "circumcision, and Sabbaths, and sacrifices," and when Christ does take up the Hebrew law, as in 5:38-39, he, to Faustus' mind, destroys the law and replaces it with a new one. From these considerations Faustus concludes that in Matt 5:17 Christ was referring to the law of Truth as described in Rom 8:2 (XIX.2-3). ${ }^{14}$ Against Faustus, Augustine simply asserts that it is "quite plain" that the law referred to in Matt 5:17 is the law given by Moses (XIX.7). ${ }^{15}$ Consequently, he accuses Faustus of evading the problem of Deut 12:32, rather than trying to understand the how Matt 5:17 may be reconciled with it. According to Augustine, Deut 12:32 poses no problem for the interpretation of Matt $5: 17$, for "the law is fulfilled by living as it enjoins," not by adding to it (XVII.6). ${ }^{16}$ As Hebblethwaite remarks, for Augustine to fulfill "means to put into practice, to perform effectively." "17 The key to understanding the implications of Matt 5:17, then, lies in understanding what it is that the law contains that must be put into practice. According to Augustine, the law contains moral precepts and prophecies, and Christ, as "grace and truth," fulfills both of these:

The law, then, is fulfilled both by the observance of its precepts and by the accomplishment of its prophecies. For 'the law was given by Moses, but grace

\footnotetext{
${ }^{13}$ Augustine, "Reply to Faustus the Manichaean [Contra Faustum Manichaeum]," 235. As Hebblethwaite explains, Faustus can only understand fulfillment (adimpletio) in terms of adding to something pre-existing. Hebblethwaite, $511-12$.

${ }^{14}$ Augustine, "Reply to Faustus the Manichaean [Contra Faustum Manichaeum]," 239-40. See also Hebblethwaite's discussion of this aspect of the debate between Augustine and Faustus. Hebblethwaite, 512.

${ }^{15}$ Augustine, "Reply to Faustus the Manichaean [Contra Faustum Manichaeum]," 241.

${ }^{16}$ Ibid., 236.

${ }^{17}$ Hebblethwaite, 512.
} 
and truth came by Jesus Christ.' The law itself, by being fulfilled becomes grace and truth. Grace is the fulfillment of love, and truth is the accomplishment of the prophecies. And as both grace and truth are by Christ, it follows that He came not to destroy the law, but to fulfill it; not by supplying any defects in the law, but by obedience to what is written in the law. (XVII.6) ${ }^{18}$

In order to explain satisfactorily how Christ fulfills the law by obedience to what is written in it, it would be best to first discuss how Christ fulfills the prophecies in the law through truth—and what implications this has for the abiding validity of the ritual law — and then to discuss how Christ fulfills the law's precepts through grace.

As in his commentary on the Sermon on the Mount, Augustine's interpretation of Matt 5:17 in Contra Faustum Manichaeum does not compel him to affirm the abiding validity of the ritual law. Faustus objects to Augustine's interpretation of 5:17 on the grounds that it would compel Christians to keep the ritual aspects of the law. Faustus asks his opponent, if his interpretation is correct:

Shall we come under the law, since Christ has not destroyed, but fulfilled it? Shall we by circumcision add shame to shame, and believe that God is pleased with such sacraments? Shall we observe the rest of the Sabbath, and bind ourselves in the fetters of Saturn? Shall we glut the demon of the Jews, for he is not God, with the slaughter of bulls, rams, and goats, not to say of men; and adopt, only with greater cruelty, in obedience to the law and the prophets, the practices on account of which we abandoned idolatry? (XVIII.2) ${ }^{19}$

Leaving aside the maliciousness of Faustus' remarks, he poses a significant dilemma for Augustine: if the law is fulfilled through Christ by obedience to it, then why do you and your fellow Catholics not obey its precepts? Moreover, Faustus asks Augustine why Christ himself, if

\footnotetext{
${ }^{18}$ Augustine, "Reply to Faustus the Manichaean [Contra Faustum Manichaeum]," 236. See also Hebblethwaite's discussion of how Augustine divides the law into its moral precepts and its ritual precepts, which division I also adopt in this essay. Hebblethwaite, 513.

${ }^{19}$ Augustine, "Reply to Faustus the Manichaean [Contra Faustum Manichaeum]," 237, 240-41. Faustus repeats the same sort of objection specifically in connection with violating the Sabbath and points out the severe punishment (Deut 27:15) Christians would be subject to if Augustine's understanding of the abiding validity of the law is correct (XIX.4-6).
} 
he came to fulfill the law by obedience to it, violates the law by censuring circumcision, by not observing the Sabbath nor commanding it to be observed, by declaring all foods clean, and by doing away with sacrifice in favour of mercy, according to his interpretation of Matt 23:15, 15:11, and 9:13 (XVII.2). ${ }^{20}$ Augustine does not deny that Christ in these passages seems to be breaking the law that he came to fulfill, but he explains that, in truth, neither Christ nor, by extension, Christians destroy the law when they fail to perform its ritual aspects, for:

The things in the law and the prophets which Christians do not observe, are only the types of what they do observe. These types were figures of things to come, and are necessarily removed when the things themselves are fully revealed by Christ, that in this removal the law and the prophets may be fulfilled. (XVIII.4) ${ }^{21}$ Not one stroke of the law shall pass away from it (Matt 5:18), but, for Augustine, not all of the law is accomplished in the same way. According to Augustine, the ritual aspects of the law were delivered to Jews for actual observance, for at that time the reality that they prefigured had not yet appeared. However, once this reality appeared in the form of Christ, Christians were no longer bound to "observe the types," but to "read them to see their meaning" (XVIII.4). ${ }^{22}$ For example, while the sacrifice of bulls, lambs, and goats was once to be performed in actuality, now by virtue of Christ's reality the reader is to understand that in these sacrifices 'the bull represents Christ, because with the horns of His cross He scatters the wicked; the lamb, from His matchless innocence; the goat, from His being made in the likeness of sinful flesh, that by $\sin \mathrm{He}$ might condemn sin" (XVIII.6). ${ }^{23}$ Accordingly, Augustine thinks, now that what was prefigured in these sacrifices has become reality, these figures become "superfluous or misleading"

\footnotetext{
${ }^{20}$ Ibid., 237.

${ }^{21}$ Ibid.

${ }^{22}$ Ibid., 238.

${ }^{23}$ Ibid.
} 
(XIX.8). ${ }^{24}$ Following this principle, Augustine shows how circumcision, the dietary laws, the Sabbath, ritual sacrifices, the feast of unleavened bread, the feast of the paschal lamb, the feast of the new moon, ritual ablutions, and the feast of tabernacles are types of Christ and therefore need no longer be observed after the fulfillment of the law in Christ (XIX.9-10). ${ }^{25}$ Thus, Augustine concludes that, since the intention of the abovementioned observances was to prefigure Christ, neither Christ nor Christians destroy the law when they fail to observe them, but rather they fulfill the law, since they acknowledge this intention (XIX.11). ${ }^{26}$ As Hebblethwaite remarks, Augustine accepts "the Jewish Law, wholly and without reservation, but he accepts it as the symbolic foreshadowing of the New Testament revelation," 27 thus exempting himself from being committed to the observance of the ritual law.

Although Augustine believes that Matt 5:17 means that Christians have been exempted from observing the "typical sacraments," nevertheless, they are still bound by the "moral precepts" of the law, which Christ also fulfills through grace (XIX.18). ${ }^{28}$ Augustine explains, following 2Cor 3:6, that before "we received in humility the grace of the Spirit, the letter was only death to us, for it required obedience which we could not render" (XIX.7). ${ }^{29}$ Before Christ, the law could not be put into practice, for then, as Augustine explains in one of his sermons, following Paul in Gal 3:21-22 and Rom 5:20, the purpose of the law was not "to heal the infirm,

\footnotetext{
${ }^{24}$ Ibid., 242.

${ }^{25}$ Ibid., 242-3. Hebblethwaite provides a good summary of the way in which these practices signify Christ. Hebblethwaite, 513 .

${ }^{26}$ Augustine, "Reply to Faustus the Manichaean [Contra Faustum Manichaeum]," 243.

${ }^{27}$ Hebblethwaite, 513.

${ }^{28}$ Augustine, "Reply to Faustus the Manichaean [Contra Faustum Manichaeum]," 246.

${ }^{29}$ Ibid., 242.
} 
but to discover and to manifest them" (LXXV.2). ${ }^{30}$ After the advent of Christ, however, Augustine argues that it becomes possible for believers to learn from Christ "to be meek and lowly in heart" and consequently to be obedient to the law-in this consists the "grace of the Spirit" that he delivers (XIX.7). ${ }^{31}$ Christ thus fulfills the moral precepts of the law by enabling those who learn from him to keep them. Moreover, Christ fulfills the law by interceding and obtaining pardon for those who have received his grace and failed to keep the law on account of its great exigency, so that "what we fail in through weakness is supplied by His perfection" (XIX.7). ${ }^{32}$ Thus, through grace and his intercession on behalf of believers, Christ ensures that the moral precepts of the law are put into practice and therefore fulfilled.

Insofar, then, as Christ came to fulfill the moral precepts of the law, the "antitheses" (Matt 5:21-48) are not, for Augustine, truly antithetical to the law, but are a means of ensuring that the moral precepts are fulfilled. As we have seen, Faustus believed that the antitheses pointed to, as Hebblethwaite writes, "the complete abandonment of the Mosaic Law,"33 citing Christ's command to turn the other cheek in Matt 5:39 as evidence a complete reversal of the law in Matt 5:38. Against Faustus, however, Augustine shows that the antitheses actually fulfill the law's true purposes (XIX.20-26). ${ }^{34}$ For example, in the case of Matt 5:38-39, Christ's command to turn to other cheek rather than to claim an eye for an eye in cases of injustice does not destroy the purpose of this law, for both of these laws are "intended to check the vehemence of hatred,

\footnotetext{
${ }^{30}$ Augustine, "Sermons on Selected Lessons of the New Testament," in A Select Library of the Nicene and PostNicene Fathers of the Christian Church, ed. Philip Schaff (Grand Rapids: Eerdmans, 1956), 476.

${ }^{31}$ Augustine, "Reply to Faustus the Manichaean [Contra Faustum Manichaeum]," 242.

32 Ibid.

${ }^{33}$ Hebblethwaite, 514.

${ }^{34}$ Augustine, "Reply to Faustus the Manichaean [Contra Faustum Manichaeum]," 247-50.
} 
and to curb the impetuosity of angry passion" (XIX.25). ${ }^{35}$ As Augustine explains, the principle of an eye for an eye in justice guards against one's desire to exact revenge in excess of the injury. However, "there is a just revenge due to the injured person from his assailant" (XIX.25). ${ }^{36}$ Although there "is no injustice in asking back a debt," nevertheless, Augustine explains: ... since it is sinful to wish to be revenged with an unjust excess, ... the man who wishes for no revenge at all is further from the sin of an unjust revenge. It is sin to demand more than is due, though it is no sin to demand a debt. And the best security against the sin of making an unjust demand is to demand nothing, especially considering the danger of being compelled to pay the debt to Him who is indebted to none. (XIX.25) ${ }^{37}$

Thus, here and in the other antitheses, Christ's remarks are either "explanatory of what the law stated less distinctly" in its original form, or "a means of securing the design intended by the law" (XIX.27). ${ }^{38}$ However, Augustine hastens to add that it is not merely in his role as an expounder of the law that Christ fulfills it, for the substance of the antitheses can be found in passages throughout the OT; it is rather through his grace, first and foremost, that he enables the believer to keep the law. The lack of this grace was, according to Augustine, what prevented Jews who had heard the same expositions in their scriptures from keeping the law (XIX.28-30). ${ }^{39}$ Consequently, Augustine's understanding of how Christ fulfills the moral precepts of the law in Contra Faustum Manichaeum revises and develops his understanding of how this is accomplished in his commentary on the Sermon on the Mount by emphasizing the role that grace

\footnotetext{
${ }^{35}$ Ibid., 249.

${ }^{36}$ Ibid.

${ }^{37}$ Ibid.

${ }^{38}$ Ibid., 250.

${ }^{39}$ Ibid., 250-52.
} 
plays in the fulfillment of the law over and above Christ's teaching of a greater righteousness in the antitheses.

Nevertheless, in both his commentary on the Sermon on the Mount and Contra Faustum Manichaeum, Augustine understands Matt 5:17 to affirm the abiding validity of the moral precepts of the law, fulfilled now through Christ's grace and teaching, but to deny the continuing validity of the ritual precepts, which have either been understood allegorically or been superseded by the reality that they were intended to represent. ${ }^{40}$ Augustine, then, has a high regard for the abiding validity and value of the law; however, his esteem of the law is contingent on it being understood in relation to Christ, who enabled it to be put into practice. $^{41}$

\section{The Historical Context of Augustine's Interpretation of Matt 5:17}

In order to understand what historical reasons Augustine might have had for coming to this understanding of Matt 5:17, it would be best to first set the works in their historical context. Augustine composed both the commentary on the Sermon on the Mount and Contra Faustum Manichaeum in the Roman city of Hippo Regius in North Africa, having arrived there in 391 C.E. to found a monastery. ${ }^{42}$ When he wrote the commentary on the Sermon on the Mount, in 394 C.E., Augustine was serving as a priest in Hippo, having been ordained in 391 C.E. by Valerius, the bishop of Hippo at that time. ${ }^{43}$ By the time Augustine wrote Contra Faustum Manichaeum, in 397/398 C.E., Valerius had already consecrated him bishop of Hippo two years

\footnotetext{
${ }^{40}$ cf. Hebblethwaite, 513.

${ }^{41}$ For Augustine's praise of the law, see Augustine, "Reply to Faustus the Manichaean [Contra Faustum Manichaeum]," 218.

${ }^{42}$ Peter Brown, Augustine of Hippo: A Biography (Berkeley: University of California Press, 2000), 64.

${ }^{43}$ Ibid., 64, 66.
} 
earlier in 395 C.E. ${ }^{44}$ Consequently, when one examines the historical reasons Augustine may have had for arriving at his interpretation of Matt 5:17, it is not unreasonable to think that, as a priest and then a bishop in Hippo, he may have had both the interests of the Church and of his parishioners in mind.

\subsection{Influences on Augustine's Exegetical Methodology: Ambrose, Paul, and Tyconius}

Augustine's interpretation of the abiding validity of the ritual law according to Matt 5:17, which allegorizes those aspects of the law in the OT that Christians no longer keep, may have come about partly as a result of Ambrose of Milan's (339-397 C.E.) spiritual exegesis of the OT. In 384 C.E., Augustine, then in Milan, had begun to attend Ambrose's sermons. He was impressed with Ambrose's ability "to defend the Old Testament against Manichaean criticisms," which consisted chiefly of objections to the carnality and perversity of the OT's teachings in light of the spirituality of the NT. ${ }^{45}$ Ambrose, who had "incorporated the Alexandrian allegories of Philo and Origen into his own preaching," replied to these criticisms by showing how the OT could be read spiritually. ${ }^{46}$ In the Confessions Augustine relates that he was "delighted to hear Ambrose in his sermons to the people saying, as if he were most carefully enunciating a principle of exegesis: 'The letter kills, the spirit gives life' (2Cor. 3:6). Those texts which, taken literally, seemed to contain perverse teaching he would expound spiritually, removing the mystical veil" (VI.iii.6). ${ }^{47}$ Ambrose's understanding of Christianity was "radically other-worldly." ${ }^{48}$ Indeed,

\footnotetext{
${ }^{44}$ Ibid., 133, 178.

${ }^{45}$ Ibid., 74.

${ }^{46}$ Paula Fredriksen, "Excaecati Occulta Justitia Dei: Augustine on Jews and Judaism," Journal of Early Christian Studies 3, no. 3 (1995), 301.

${ }^{47}$ Augustine, Confessions, trans. Henry Chadwick (Oxford: Oxford UP, 1998), 94.

${ }^{48}$ Brown, 75 .
} 
for Ambrose, the central problem for the interpreter of the Bible was "to understand the 'spiritual' message of the Old Testament in terms of allegories evolved by the Alexandrian school," and in particular, those of Origen (ca. 185-254 C.E.). ${ }^{49}$ Although Peter Brown writes that the Origenistic approach to scripture had begun to fall out of vogue by the late fourth century - to be replaced by Augustine and Pelagius' own thoroughly Latin theology ${ }^{50}$ — it is nevertheless likely that Augustine's early responsiveness to Ambrose's exegetical methodology informed his understanding of the typological significance of the ritual law.

Augustine's tendency to interpret the First Gospel in light of the Pauline epistles may have been the fruit of the intensive study of Paul he undertook shortly before writing both the commentary on the Sermon on the Mount and Contra Faustum Manichaeum. I have noted above that Augustine's allegorical interpretation of the altar in Matt 5:23-24, as well as his view of the status of the moral precepts of the law before their fulfillment in Christ, are informed by a careful study of Paul's letters. Shortly after Valerius had ordained him priest in Hippo in 391 C.E., Augustine begged the bishop for some time to study scripture in retirement. Valerius granted Augustine's request, and the priest made a thorough and personally captivating study of the life of Paul, which, Brown states, was vital to his later life. ${ }^{51}$ Moreover, by 394 C.E., a few years before he wrote Contra Faustum Manichaeum, Augustine was delivering lectures on Romans to his friends in Carthage and was so interested in the apostle's writings that he even intended to write a commentary on the entire Pauline corpus, though he never realized this desire. $^{52}$ According to Brown, Augustine's interest in Paul was typical of the late fourth century,

\footnotetext{
${ }^{49}$ Ibid., 147.

${ }^{50}$ Ibid.

${ }^{51}$ Ibid., 201-02.

${ }^{52}$ Ibid., 144.
} 
which he describes as the "generation of S. Paul," on account of the several commentaries that had been written on his letters both in Italy and in Africa at that time. ${ }^{53}$ Thus, Augustine's own intensive study of Paul and the spirit of Paulinism prevalent when he wrote his commentary on the Sermon on the Mount and Contra Faustum Manichaeum may account, in part, for his Pauline interpretation of Matt 5:17.

Finally, Augustine's reading of Tyconius' (fl. 370-390 C.E.) Rules may have contributed both to his typological understanding of the ritual law and to his tendency towards a Pauline interpretation of Matthew. Tyconius, a fellow African, was a significant figure in the "generation of S. Paul," a "drastic interpreter" of the apostle, as Brown describes him. ${ }^{54}$ Tyconius wrote a manual on exegesis called the liber regularum, which, informed by his study of Paul, "laid out rules for finding one's way through 'the immense forest of prophecy' that depended on the use of typology." "55 Augustine was sufficiently impressed with this manual that he recommended it to his fellow workers in the African Church as an authoritative guide to biblical interpretation. ${ }^{56}$ Paula Fredriksen argues that Augustine's encounter with Tyconius' Rules occurred in 394 C.E., shortly before he composed Contra Faustum Manichaeum. ${ }^{57}$ Both Fredriksen and Brown concur that Tyconius' influence on Augustine's approach to scripture was “decisive," and Fredriksen even goes so far as to say that Augustine took over from Tyconius, not simply a typological understanding of scripture, but also the very notion of "the religious

\footnotetext{
${ }^{53}$ Ibid.

${ }^{54}$ Ibid., 269.

${ }^{55}$ Fredriksen, 312.

${ }^{56}$ Brown, 268-69.

${ }^{57}$ Fredriksen, 311-12.
} 
validity of the Law."58 Thus, it seems that Tyconius' Rules may have significantly shaped Augustine's understanding of the typological significance of the ritual law and his Pauline interpretation of Matthew.

\subsection{Influences on Augustine's Exegesis: The Religious Climate of North Africa}

\subsubsection{African Christianity During Augustine's Youth}

Augustine's exposure to the diverse nature of African Christianity during his youth may have played a role in his understanding of the abiding validity of the law later in his life. Augustine was born in 354 C.E. in Thagaste in North Africa and received much of his education in Madaura and Carthage. The picture of Christianity Augustine would have formed in his youth, then, would be thoroughly African in nature. As Brown relates, at school Christianity would have been presented to Augustine as a form of "True Wisdom," with Christ as the quintessential teacher leading a "coterie of budding philosophers." 59 In the streets of Thagaste and Carthage, however, Augustine would have encountered another sort of Christianity, one that, by the standard of his schoolmasters and the "cultivated" elite, was "exceptionally narrow and conservative: many of its institutions and practices may have stemmed directly from the Jewish synagogue." 60 For these Christians, the Bible was "as rigid and demanding as the old Jewish law."61 Against both of these kinds of Christianity stood the Manichaeans, who had arrived in Carthage in 297 C.E., and were particularly active among the students of Carthage during Augustine's time there. The Manichaeans rejected the OT wholesale and professed a purely spiritual religion. Augustine joined their movement at the age of twenty and remained a

\footnotetext{
${ }^{58}$ Brown, 269; Fredriksen, 312-13.

${ }^{59}$ Brown, 30-31.

${ }^{60}$ Ibid., 31 .

${ }^{61}$ Ibid., 32.
} 
"Hearer" - a sort of catechumen - with them for nine years before leaving their order in bitter disappointment over their wholly spiritual theology (in which Ambrose's sermons played no small role) and converting to Catholic Christianity. ${ }^{62}$ Granted these three conceptions of the nature of Christianity to which Augustine had been exposed in his youth, it is perhaps not coincidental that when he did broach the question of the validity of the law, his understanding of its abiding significance seemed to show the influence of all three: he neither rejected the validity of the Jewish law wholesale (showing perhaps the influence of traditional African Christianity and Augustine's disappointment with the Manichaeans) ${ }^{63}$ nor affirmed the law in its entirety, which would compel him to obey its ritual precepts (showing perhaps the influence of spiritual Christianity, both via his schoolmasters and the Manichaeans).

\subsubsection{Judaism in North Africa in the Late Fourth Century}

Since the question of the abiding validity of the law for Christians is tied to the question of the relationship between Judaism and Christianity, Augustine's attitudes towards the Jews in and around Hippo may have influenced his understanding of Matt 5:17. Archaeological and epigraphic evidence indicate that Jews had settled in significant numbers throughout North Africa by the late fourth century. ${ }^{64}$ Moreover, Jerome (347-419/20 C.E.) relates that during his and Augustine's time there was "a continuous chain of Jewish settlements ... from Mauretania in the west through the Maghreb, Egypt and Palestine to India in the east." ${ }^{.65}$ In Africa at that time

\footnotetext{
${ }^{62}$ Ibid., 32-35. See also Augustine, Confessions, 90-110.

${ }^{63}$ One of his writings on Matt 5:17 is, after all, directed against Faustus the Manichaean.

${ }^{64}$ Franklin T. Harkins, "Nuancing Augustine's Hermeneutical Jew: Allegory and Actual Jews in the Bishop's Sermons," Journal for the Study of Judaism 36, no. 1 (2005): 45-46.

${ }^{65}$ H. Z. Hirschberg, A History of the Jews in North Africa, trans. H.Z. Hirschberg, rev. 2d ed., vol. 1 (Leiden: E.J. Brill, 1974), 55.
} 
there was also a significant number of half-, one-third-, or one-quarter-Judaized Christians. ${ }^{66}$ In the absence of actual Jews, Jewish ideas had also penetrated the fabric of African civilization through Jewish proselytizing, which failed to win many converts, but piqued the curiosity of many Africans in Jewish ideas. ${ }^{67}$ Some scholars have also argued that Semitic religious ideas permeated African Christianity through the Punic language, which is similar to Hebrew (Augustine sometimes appealed to Punic for assistance in explaining untranslated Hebrew words in the Bible) and which was spoken outside of the African cities. ${ }^{68}$ Augustine's attitude to the Jews he saw around him and their ideas that permeated his culture was mixed. On the one hand, he seemed to accept the authority of Jewish scholarship, at least in some cases, for understanding the literal significance of the Bible, for he favourably relates a story in which the bishop of Oea consulted the city's Jews on the precision of Jerome's translation of qiqāyōn in Jonah 4:6. When they found that it was misleading, the bishop corrected the translation. ${ }^{69}$ Augustine's positive evaluation of Jewish learning also seems to be indicated by the presence of haggadic elementsfor example, he knew the tradition that the Book of Generations of Adam contains all wisdom and the tradition of Adam's wives - in the City of God. ${ }^{70}$ In spite of these positive evaluations of Jewish ideas, one cannot overlook the fact that Augustine wrote an entire treatise against the Jews entitled Adversus Judaeos. Hebblethwaite, however, remarks that in this treatise Augustine's chief accusation against the Jews is that they cannot read their own scriptures

\footnotetext{
${ }^{66}$ Ibid., 54.

${ }^{67}$ Harkins, 45-46.

${ }^{68}$ Peter Brown, "Christianity and Local Culture in Late Roman Africa," in Religion and Society in the Age of Saint Augustine, ed. Peter Brown (London: Faber and Faber, 1972), 280-86; Brown, Augustine of Hippo: A Biography, 186.

${ }^{69}$ Hirschberg, 80 .

${ }^{70}$ Ibid., 81 .
} 
properly, since they lack the "key of spiritual exegesis," and that, in general, Augustine is much more reserved in his criticism of Jews than, for example, John Chrysostom (347-407 C.E.). ${ }^{71}$ Note here, that Augustine does not accuse the Jews of having faulty writings- - he cannot accuse them of this without adopting the Manichaean position viz. the OT—but that they do not know how to read them. Augustine's attitudes towards Jews and Jewish ideas, then, seem to offer a parallel to the conclusion he arrives at in his interpretation of Matt 5:17. The law, like Jewish ideas, cannot be rejected simply because it is of Jewish origin. Christians do not have an exclusive purchase on the truth. Consequently, the same law that was given to the Jews abides for Christians. However, the law as interpreted by the Jews is lacking, for they do not know how to read their own scriptures, and so must be fulfilled.

Whatever Augustine's personal attitudes were towards Jews, as a Roman citizen living under the laws of the empire in Hippo, his exegesis of Matt 5:17 may have been influenced by imperial legislation concerning Jews. By 391 C.E., when Augustine arrived there, Hippo Regius was already a very old and splendid Roman city. It was the birthplace of Suetonius, the "biographer of the first Emperors." "72 As such, Hippo was subject to Roman law. Moreover, it was likely that its citizens would be privy quite quickly to the promulgation of new laws in the capitol, for Hippo was a busy shipping port and supplied corn to Italy. ${ }^{73}$ Although legislation concerning Jews in the late fourth century was initially relatively benevolent, under the emperor Honorius (395-423 C.E.) it became increasingly discriminatory. During the emperor Theodosius' reign (379-95 C.E.), Jews were recognized as Roman citizens and the emperor had

\footnotetext{
${ }^{71}$ Hebblethwaite, 515 .

${ }^{72}$ Brown, Augustine of Hippo: A Biography, 183.

${ }^{73}$ Ibid., 185-86.
} 
proclaimed laws for the protection of synagogues. ${ }^{74}$ Theodosius had even commanded Ambrose, in 388 C.E., to rebuild the local synagogue of the Jews in Milan with Church funds, although Ambrose ultimately refused to obey him. ${ }^{75}$ Even the remarkably tolerant Theodosius, however, proclaimed that Jews had no right to make a will and forbade Christian men from marrying Jewish women and Jewish men from marrying Christian women, labeling such unions adulterous. $^{76}$ When Honorius became emperor, shortly thereafter he issued discriminatory laws against the Jews and singled out for "especial wrath" a Judaizing sect of Christians known as the caelicolae, whose leader Augustine had invited to a disputation with him. ${ }^{77}$ Thus, on account of the prevailing stigma against Jews in the empire, Augustine may have been wary of arriving at an interpretation of Matt 5:17 that would associate him too closely with the Jews or the caelicolae, and this may have especially influenced his views on the abiding validity of the ritual law, since this is the most ready identifier of a Jew's beliefs.

\subsubsection{Christian Sects}

Finally, Augustine's efforts as a priest and bishop to combat the Donatists may have led him, in part, to reject the validity of the ritual law. ${ }^{78}$ The Donatists were a Christian sect that regarded their religion as a "Law" and identified themselves with the Maccabees, who had died for their laws. They were very concerned with matters of ritual purity, for they considered it as

\footnotetext{
${ }^{74}$ Solomon Grayzel, "The Jews and Roman Law," The Jewish Quarterly Review 59, no. 2 (1968), 98-99; Hirschberg, 54. response to the rejection of the OT by the Manichaeans. For more on this possible connection, see Hebblethwaite, 511.
} 
the key to maintaining their special relationship with God, understanding themselves as his chosen people, akin to the ancient Israelites. Accordingly, they made rigorous distinctions between "clean" and "unclean" objects and actions. ${ }^{79}$ In Numidia, the larger ecclesiastical province within which Hippo was circumscribed, the Donatists were in the majority compared to the Catholics and were considered the established church. Accordingly, Augustine and his fellow Catholic priests had to distinguish themselves from the Donatists, lest they be consumed by the majority, and so they "took the offensive against the Donatist church" from 393 C.E. onwards. ${ }^{80}$ Insofar, then, as the Donatists placed a high value on ritual purity, Augustine may have consciously or unconsciously wished to distance himself from their sect by rejecting the abiding validity of the ritual law understood literally.

\section{Conclusion}

In his commentary on the Sermon on the Mount and Contra Faustum Manichaeum, Augustine understands Matt 5:17 to affirm the abiding validity of the moral precepts of the law, which are fulfilled practically in Christ through his grace and teaching. The ritual precepts of the law, however, are no longer binding on Christians in their literal force, for, Augustine argues, the reality of Christ has shown that they were intended merely as types of his reality, and now that this reality is present, the types have been superseded. Insofar as Augustine's interpretation of Matt 5:17 makes use of allegory and typology, Ambrose of Milan and Tyconius may have influenced his approach to this verse via their own allegorical readings of scripture that he had been exposed to. Moreover, Augustine's tendency to interpret Matthew with reference to Paul

\footnotetext{
${ }^{79}$ Brown, Augustine of Hippo: A Biography, 213-14.

${ }^{80}$ Ibid., 222-23.
} 
may have been the fruit of his having undertaken an intensive study of Paul before composing these two works. Finally, Augustine's affirmation of the abiding validity of the law in part, rather than as a whole or not at all, may have been influenced by his early exposure to the diversity of African Christianity, his opinion of Jews and that of the empire within which he lived, and his struggle against the Manichaean and Donatist sects. 


\section{Bibliography}

Augustine. "Our Lord's Sermon on the Mount, According to Matthew [De Sermone Domini in Monte Secundum Matthaeum.]." In A Select Library of the Nicene and Post-Nicene Fathers of the Christian Church, ed. Philip Schaff, 6, 1-63. Grand Rapids: Eerdmans, 1956.

. "Reply to Faustus the Manichaean [Contra Faustum Manichaeum]." In A Select Library of the Nicene and Post-Nicene Fathers of the Christian Church, ed. Philip Schaff, 4, 155-345. Grand Rapids: Eerdmans, 1956.

. "Sermons on Selected Lessons of the New Testament." In A Select Library of the Nicene and Post-Nicene Fathers of the Christian Church, ed. Philip Schaff, 6, 237-545. Grand Rapids: Eerdmans, 1956.

. Confessions. Translated by Henry Chadwick. Oxford: Oxford UP, 1998.

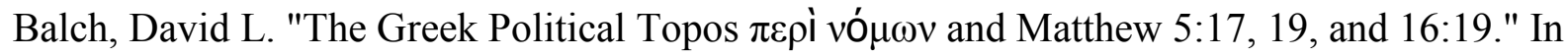
Social History of the Matthean Community, ed. David L. Balch, 68-84. Minneapolis: Fortress Press, 1991.

Brown, Peter. "Christianity and Local Culture in Late Roman Africa." In Religion and Society in the Age of Saint Augustine, ed. Peter Brown, 279-300. London: Faber and Faber, 1972. . Augustine of Hippo: A Biography. Berkeley: University of California Press, 2000.

Fredriksen, Paula. "Excaecati Occulta Justitia Dei: Augustine on Jews and Judaism." Journal of Early Christian Studies 3, no. 3 (1995): 299-324.

Grayzel, Solomon. "The Jews and Roman Law." The Jewish Quarterly Review 59, no. 2 (1968): 93-117.

Harkins, Franklin T. "Nuancing Augustine's Hermeneutical Jew: Allegory and Actual Jews in the Bishop's Sermons." Journal for the Study of Judaism 36, no. 1 (2005): 41-64.

Hebblethwaite, Peter. "St. Augustine's Interpretation of Matthew 5,17." In Studia Patristica, ed. Elizabeth A. Livingstone, 16.2, 511-16. Berlin: Akademie Verlag, 1985.

Hirschberg, H. Z. A History of the Jews in North Africa. Translated by H.Z. Hirschberg. Vol. 1. rev. 2 d ed. Leiden: E.J. Brill, 1974.

Klein, Elka. Jews in the Codex Justinianus [web page]. accessed 12 April 2007; Available from http://homepages.uc.edu/ kleinei/cjc-jews.htm. 
Luz, Ulrich. Matthew in History: Interpretation, Influence, and Effects. Minneapolis: Fortress Press, 1994. . Studies in Matthew. Grand Rapids: Eerdmans, 2005.

Saldarini, Anthony J. Matthew's Christian-Jewish Community. Chicago: University of Chicago Press, 1994.

Snodgrass, Klyne. "Matthew and the Law." In Treasures New and Old: Recent Contributions to Matthean Studies, ed. David R. Bauer and Mark Allan Powell, 99-127. Atlanta: Scholars Press, 1996. 